\title{
Prevalence, genetic identity and vertical transmission of Babesia microti in three naturally infected species of vole, Microtus spp. (Cricetidae)
}

Katarzyna Tołkacz' ${ }^{1}$ Małgorzata Bednarska', Mohammed Alsarraf', Dorota Dwużnik', Maciej Grzybek², Renata Welc-Falęciak', Jerzy M. Behnke ${ }^{3}$ and Anna Bajer ${ }^{1 *}$

\begin{abstract}
Background: Vertical transmission is one of the transmission routes for Babesia microti, the causative agent of the zoonotic disease, babesiosis. Congenital Babesia invasions have been recorded in laboratory mice, dogs and humans. The aim of our study was to determine if vertical transmission of B. microti occurs in naturally-infected reservoir hosts of the genus Microtus.

Methods: We sampled 124 common voles, Microtus arvalis; 76 root voles, M. oeconomus and 17 field voles, M. agrestis. In total, 113 embryos were isolated from 20 pregnant females. Another 11 pregnant females were kept in the animal house at the field station in Urwitałt until they had given birth and weaned their pups $(n=62)$. Blood smears and/or PCR targeting the $550 \mathrm{bp} 18 \mathrm{~S}$ rRNA gene fragment were used for the detection of B. microti. Selected PCR products, including isolates from females/dams and their embryos/pups, were sequenced.

Results: Positive PCR reactions were obtained for 41\% (89/217) of the wild-caught voles. The highest prevalence of B. microti was recorded in $M$. arvalis $(56 / 124 ; 45.2 \%)$, then in $M$. oeconomus $(30 / 76 ; 39.5 \%)$ and the lowest in M. agrestis $(3 / 17 ; 17.7 \%)$. Babesia microti DNA was detected in $61.4 \%(27 / 44)$ of pregnant females. Vertical transmission was confirmed in $81 \%(61 / 75)$ of the embryos recovered from Babesia-positive wild-caught pregnant females. The DNA of B. microti was detected in the hearts, lungs and livers of embryos from $98 \%$ of $M$. arvalis, $46 \%$ of $M$. oeconomus and $0 \%$ of $M$. agrestis embryos from Babesia-positive females. Of the pups born in captivity, $90 \%$ were born to Babesia-positive dams. Babesia microti DNA was detected in 70\% (35/50) of M. arvalis and 83\% (5/6) of M. oeconomus pups. Congenitally acquired infections had no impact on the survival of pups over a 3-week period post partum. Among 97 B. microti sequences, two genotypes were found. The IRU1 genotype (Jena-like) was dominant in wild-caught voles (49/53; 92\%), pregnant females $(9 / 11 ; 82 \%)$ and dams $(3 / 5 ; 60 \%)$. The IRU2 genotype (Munich-like) was dominant among B. microti positive embryos (20/27; 74\%) and pups (12/17; 71\%).
\end{abstract}

Conclusion: A high rate of vertical transmission of the two main rodent genotypes of $B$. microti was confirmed in two species of naturally infected voles, M. arvalis and $M$. oeconomus.

Keywords: Babesia microti, Prevalence, Genotyping, Vertical transmission, Congenital infection, Voles, Microtus

\footnotetext{
*Correspondence: anabena@biol.uw.edu.pl

${ }^{1}$ Department of Parasitology, Institute of Zoology, Faculty of Biology,

University of Warsaw, 1 Miecznikowa Street, 02-096 Warsaw, Poland

Full list of author information is available at the end of the article
} 


\section{Background}

Voles of the genus Microtus constitute the main natural hosts of the protozoan parasite Babesia microti $[1,2]$. In Poland, the highest recorded prevalence of $B$. microti is from the common vole (35-72\% in $M$. arvalis), and then from the root vole $(32-50 \%$ in $M$. oeconomus) [2-4]. There are few data for the less-well studied field vole, $M$. agrestis [3].

Babesia microti is an important zoonotic parasite, responsible for the great majority of human cases of babesiosis reported in the USA $[5,6]$. In contrast, far fewer cases of human $B$. microti infections have been reported to date in Europe [7-9], although strains known to be pathogenic for humans have been isolated from common and root voles in north-eastern Poland [2].

Ticks of the genus Ixodes are the main vectors of Babesia parasites, with the common tick, Ixodes ricinus, being the main vector in Europe [10-12]. Prevalence in ticks is usually low (1-10\%). Ixodes ricinus instars feed mainly on woodland rodents such as Myodes glareolus and Apodemus flavicollis [13] and are less abundant on rodents inhabiting open grasslands, such as voles from the genus Microtus. However, Microtus spp. generally show high prevalence of $B$. microti despite low infestation by $I$. ricinus instars and low prevalence of $B$. microti in this tick species. A similar phenomenon has been recognized in a rodent community near Omsk, Russia [14], where 30-60\% of Myodes and Microtus spp. voles were found to be infected with $B$. microti but no $B$. microti infection was detected in ticks collected from rodents and from the environment [14]. We hypothesized that the high prevalence of B. microti in Microtus spp. in our area is maintained by alternative routes of transmission, the most likely of which is vertical transmission from female voles to their offspring.

Vertical transmission of $B$. microti has been clearly demonstrated recently in BALB/c mice in our laboratory [15], with up to $100 \%$ success, and some cases of congenital babesiosis have been reported recently in the literature in dogs [16-18]. Congenital babesiosis has been recognized also in newborn human babies in the USA [19-21].

The aim of the current study was to test the hypothesis that vertical transmission of $B$. microti occurs in naturally infected voles. Accordingly, we first planned to determine the prevalence of $B$. microti in embryos dissected from naturally infected voles, thus completely eliminating the possibility of vector-borne transmission. Then, to eliminate the possibility that the tissues of the embryos may have been contaminated by maternal blood, despite all the precautions that had been taken, and to evaluate the impact of congenital infection on the survival of pups, we planned to maintain in captivity naturally infected pregnant female voles, completely deprived of ectoparasites, until a suitable period after parturition when individual sampling of the blood of the pups was possible. Thus we could assess the prevalence of congenitally transmitted $B$. microti infection in the pups.

\section{Methods}

The study was conducted within the Mazury Lake District of north-eastern Poland (Urwitałt, near Mikołajki; 53 $\left.48^{\prime} 50.25^{\prime \prime} \mathrm{N}, 21^{\circ} 39^{\prime} 7.17^{\prime \prime} \mathrm{E}\right)$, within an extensive forest and old field system adjacent to Lakes Śniardwy and Łuknajno. At the time of the study, the long-abandoned, previously intensively cultivated fields in the study sites had succeeded to a mixed vegetation of scrub and long grass. Trap lines extended up the gentle hills (greatest elevation $5 \mathrm{~m}$ ) from two small ponds, giving a gradation in physical conditions and vegetation: from marshland, submerged during rainy weather, to dry grassland. We trapped three species of voles in these different microhabitats: $M$. arvalis individuals on the dry upper sections of the hills; $M$. oeconomus in the belts of marshland around the ponds and $M$. agrestis in the intermediate zones. Trapping of rodents took place in summer (August and early September) in 2013 and 2014. Rodents were live trapped using mixed bait comprising fruit (apple), vegetables (carrot or cucumber) and grain. Two traps were set every $10 \mathrm{~m}$ along the trap lines at dusk, and checked and closed the following morning to prevent animals entering during daytime and to avoid losses from excessive heat from exposure of traps to direct sunlight. Traps were then re-baited and re-set on the following afternoon. Traps were also closed during periods of intensive rainfall. At each location trapping was continued for at least 5 consecutive nights. All captured voles were transported in their traps to the laboratory for inspection.

In 2013, the autopsies were carried out under terminal isoflurane anesthesia. Animals were weighed to the nearest gram, and total body length and tail length were measured in millimeters. Animals were allocated to three age classes (juveniles, young adults and adults), based on body weight and nose-to-anus length together with reproductive condition (scrotal, semi-scrotal or non-scrotal for males; lactating, pregnant or receptive for females) [1, 22]. Ectoparasites (ticks, fleas, mites) were removed using forceps and preserved in 99.8\% methanol. A blood sample was taken from the heart for direct preparation of two thin blood smears and storage in 0.001 M EDTA (anticoagulant) for subsequent DNA extraction. The upper (maxilla) and lower (mandible) jawbones of autopsied individuals were inspected to confirm identity of the vole species based on the known dental formula for each, and especially to distinguish 
between juvenile individuals of $M$. oeconomus and $M$. agrestis [23].

Initially vole species were distinguished based on their appearance (fur colour: grey and yellowish hair with brighter belly and legs: $M$. arvalis; brown-reddish fur with dark belly and legs: $M$. agrestis; dark brown fur with dark belly and black legs: $M$. oeconomus), and on body weight and body measurements, as follows: (i) $M$. arvalis: mean weight $25.4 \mathrm{~g}$; mean body length $10.4 \mathrm{~cm}$; mean tail length $3.1 \mathrm{~cm}$; (ii) $M$. agrestis: mean weight $27.2 \mathrm{~g}$; mean body length $10.9 \mathrm{~cm}$; mean tail length $3.4 \mathrm{~cm}$; (iii) $M$. oeconomus: mean weight $36.6 \mathrm{~g}$; mean body length $11.9 \mathrm{~cm}$; mean tail length $4.6 \mathrm{~cm}$. Finally, we confirmed the species identity of each individual by examination of the lower molars $M_{1}$ and $M_{2}$ and the second upper molar $\left(\mathrm{M}^{2}\right)$ [23]. Embryos were isolated and frozen at a temperature of $-20{ }^{\circ} \mathrm{C}$.

In the summer of 2014, all the captured voles were live-processed. Voles were taken to the laboratory, where under non-terminal isoflurane anesthesia they were weighed to the nearest gram, and total body length and tail length were measured in millimeters. Data on age, sex and reproductive condition were recorded, and the ectoparasites (ticks, fleas, mites) carefully removed and preserved, as described above. A blood sample was taken from the tail tip of each vole (for blood smears and for preservation in EDTA to facilitate DNA extraction, as described above). Then males and juveniles were released in close proximity to the trap lines where earlier they had been caught. Females suspected of being pregnant were transferred to individual cages to establish a breeding colony of voles. The colony was maintained in the animal house at the field station in Urwitałt. Each cage contained a thick layer of standard sawdust $(c .10 \mathrm{~cm})$, water and food (grass, vegetables, fruits, grain) ad libitum together with bedding material (grass, hay, paper tubes). To prevent the development of ectoparasites (i.e. development of nymphs from engorged tick larvae), possible vectors, and to provide suitable housing conditions for pups, the cages were cleaned at least once a week. During handling, all voles from the breeding colony were inspected for ectoparasites in order to ensure vector-free conditions in the cages and animal house. No ectoparasites were noted at any time after initial caging, neither on the dams nor on the pups. Females were kept at a constant temperature of $18{ }^{\circ} \mathrm{C}$, and with a 16 (Day): 8 (Night) light-dark phase for at least 3 weeks to allow pregnancies to develop to term. Non-pregnant females were then released at their original trap lines.

Pups were kept together with their dams for one month. In the third week of life we weighed the pups and collected blood samples from the tail tip of each individual. Then pups and dams were released at the trap lines at which the dams had been caught originally.

\section{Blood collection and DNA extraction}

Two thin blood smears were prepared from drops of blood taken from the heart (autopsies) or tail tip (alive processing) of wild-caught voles and pups. Blood smears were air-dried, fixed in absolute methanol and stained with Diff Quick (Microptic, Barcelona, Spain) and Hemacolor (Merck, Darmstadt, Germany) staining kits. Molecular techniques were used for the detection of Babesia in adult voles (males and females), embryos and pups. Between $20 \mu \mathrm{l}$ (from the live-processed animals) to $200 \mu \mathrm{l}$ of whole blood (from the culled animals) were collected into 0.001 M EDTA and frozen at a temperature of $-20{ }^{\circ} \mathrm{C}$ before DNA extraction. Embryos were isolated from the uterus and individually processed (autopsies) following two washes in sterile water, to minimize contamination with maternal blood. We autopsied 113 embryos from 20 litters (16 obtained in 2013 and 4 litters from 2014 from females that succumbed under anesthesia) (Fig. 1). Organs (mainly hearts and lungs together, and brains, livers, spleens and kidneys, if distinguishable) were isolated from embryos with sterile dissecting instruments. Genomic DNA was extracted from whole blood and organs using the DNAeasy Blood \& Tissue kit (Qiagen, USA) and stored at a temperature of $-20{ }^{\circ} \mathrm{C}$. The remaining 13 litters were in earlier stages of pregnancy (1-2 trimester) and were too small (diameter of the embryo together with amniotic sac less than $1 \mathrm{~cm}$ ) to enable the isolation of specific internal organs.

\section{Molecular characterization}

Detection and genotyping of $B$. microti isolates from pregnant females and embryos, dams and pups were performed by the amplification and sequencing of the 550 bp $18 S$ rRNA gene fragment by PCR (first run) and nested-PCR (in the case of no or weak signal from the initial one-step PCR). The primers and thermal profile used in this study have been described previously [24]. Reactions were performed in $1 \times$ PCR buffer, $1 \mathrm{U}$ Taq polymerase, $1 \mu \mathrm{M}$ of each primer and $2 \mu \mathrm{l}$ of the extracted DNA sample. Negative controls were performed in the absence of template DNA. In the PCR reaction, primers GF 5 '-G(C/T)(C/T) TTG TAA TTG GAA TGA TGG-3' and GR 5'-CCA AAG ACT TTG ATT TCT CTC-3' were used for the amplification of a 559 bp fragment of $18 S r D N A$. In the first step of nested-PCR, the full-length $18 S$ rDNA was amplified with apicomplexan $18 \mathrm{~S}$ rRNA-specific primers: Crypto $\mathrm{F}$ (5'-AAC CTG GTT GAT CCT GCC AGT-3') and Crypto R (5'-GCT TGA TCC TTC TGC AGG TTC ACC TAC-3'). The PCR conditions included: $95{ }^{\circ} \mathrm{C}$ for $10 \mathrm{~min}$, followed by 45 cycles of denaturation at $95{ }^{\circ} \mathrm{C}$ for $45 \mathrm{~s}$, annealing at $60{ }^{\circ} \mathrm{C}$ for $45 \mathrm{~s}$, and extension at $72{ }^{\circ} \mathrm{C}$ for $45 \mathrm{~s}$. Final extension was at $72{ }^{\circ} \mathrm{C}$ for $7 \mathrm{~min}$, followed by a hold step at $4{ }^{\circ} \mathrm{C}$. In the second step (nested reaction), primers GR 


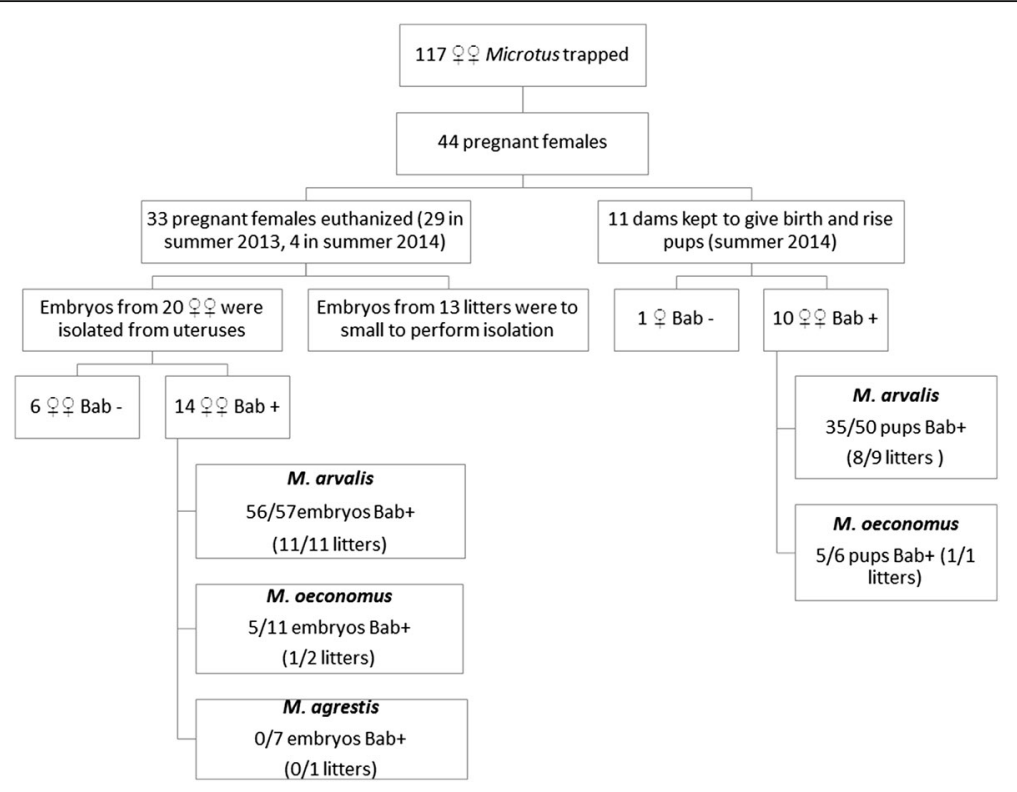

Fig. 1 The scheme of the study. Abbreviations: Bab+, voles infected with B. microti; Bab-, voles uninfected with B. microti

and GF were used. Nested PCR reactions were performed with different volumes of the first PCR product: 1 or $0.5 \mu \mathrm{l}$, or finally with $2 \mu \mathrm{l}$ of the dilution $1: 9$ in sterile water. As positive controls we used the genomic DNA of B. microti King's 67 strain or B. canis DNA extracted from dog blood [25-27].

PCR products were subjected to electrophoresis on a $1.5 \%$ agarose gel, stained with Midori Green stain (Nippon Genetics, GmbH, Düren, Germany). Selected PCR products from voles trapped in 2013 and 2014, all pregnant females and dams, and from at least two pups per litter were sequenced by a private company (Genomed S.A., Gdańsk, Poland). DNA sequence alignments and analyses were conducted using MEGA v. 6.0. [28]. Consensus sequences were compared with sequences deposited in the GenBank database using BioEdit tool [29].

\section{Statistical analysis}

The statistical approach adopted has been documented comprehensively in our earlier publications [30-33]. Prevalence (percentage of animals infected) was analysed by maximum likelihood techniques based on log-linear analysis of contingency tables. For analysis of the prevalence of Babesia in wild-caught voles, we fitted prevalence of Babesia infection as a binary factor (infected $=1$, uninfected $=0$ ) and then year (two levels: 2013, 2014), host species (three levels: $M$. arvalis, $M$. oeconomus, $M$. agrestis), host age (three levels: juvenile, young adult, adult) and host sex (two levels: males and females) as factors. Subsequent analyses were carried out for each host species separately, but without inclusion of 'host species'.

For analysis of the prevalence of Babesia in embryos, we implemented 'female infection' as a binary factor (i.e. infected/uninfected mother). For analysis of the prevalence of Babesia in pups, we implemented pup survival as a binary factor (dead $=0$ or alive $=1$ at the age of 3 weeks). Beginning with the most complex model, involving all possible main effects and interactions, those combinations not contributing significantly to explanation of variation in the data were eliminated stepwise, beginning with the highest-level interaction. A minimum sufficient model was then obtained, for which the likelihood ratio of $\chi^{2}$ was not significant, indicating that the model was sufficient in explaining the data.

Statistical analysis was carried out using SPSS v. 21.0. Multifactorial analysis of variance (ANOVA) was used for comparison of mean parameters (abundance of $B$. microti, litter size, mean weight of pup, etc.), which are reported with standard errors of their means (SE). Abundance of $B$. microti infection was calculated as the number of infected red blood cells (iRBC) in 200 fields of vision $(\times 1,000$ magnification). When samples were only positive by PCR, an intensity of $0.001 \mathrm{iRBC} / 200$ fields was implemented into quantitative statistical analysis. Fisher's exact test (INSTAT software) was used to compare the \% of infected pups between Babesia-negative and Babesia-positive females.

The success of vertical transmission to each litter, calculated as the \% of Babesia-positive pups/litter, was 
correlated with the litter size using the Spearman's rank correlation test (SPSS v. 21).

\section{Results}

Prevalence of $B$. microti in the community of voles Community structure

The number of wild-caught voles by year of study, host species, age and sex is provided in Table 1. In total, 217 voles of three species were trapped and sampled: 124 common voles, $M$. arvalis; 76 root voles, $M$. oeconomus and 17 field voles, M. agrestis. Adult individuals constituted the majority of the sampled vole community (70\%), followed by young adults (18\%); juveniles (12\%) were least frequent. Females were slightly more abundant than males (54 vs $46 \%$ ).

\section{Prevalence of $B$. microti in voles}

Prevalence of $B$. microti infection by year of study, host species and sex is provided in Table 2. In total, a positive product of the specific PCR reaction was obtained for $41 \%$ of voles in the community. The highest prevalence of $B$. microti was detected in $M$. arvalis and the lowest in $M$. agrestis (presence/absence of Babesia $\times$ host species: $\left.X^{2}=5.84, d f=2, P=0.054\right)$. Prevalence increased significantly with the age of a host (presence/absence of Babesia $\times$ age class: $\left.X^{2}=20.36, d f=2, P<0.001\right)$. Overall, prevalence of $B$. microti was higher in males than females (47 vs 36\%) but this difference was not statistically significant, and there were no differences in prevalence between the years of study (Table 2). However, there were significant differences in the pattern of infections among male and female voles in the community over the two years of the study (year $\times$ host sex $\times$ presence/ absence of Babesia: $\chi^{2}=6.34, d f=1, P=0.012$ ). In 2013 prevalence of $B$. microt $i$ infection was similar in females and males (44.7 and 41.5\%, respectively) while in 2014 prevalence was markedly higher in males in comparison to females (51 vs 30\%, $P=0.012$ ).

Among field voles, prevalence of $B$. microti was the lowest of all: 21.4\% in 2013 and no Babesia-positive field voles were found among the three individuals trapped in 2014.

\section{Abundance of $B$. microti infection in the community of voles}

Data on the abundance of $B$. microti infection by year of study, host species and sex is provided in Table 3 . Abundance was calculated on the basis of microscopical observation of blood smears for 121 wild-caught M. arvalis, $76 M$. oeconomus and $17 M$. agrestis. The mean abundance of $B$. microti infection, calculated for the three vole species combined, was $15.33 \pm 15.45$ (19.99 \pm 16.91 excluding M. agrestis) (Table 3).

Mean abundance of $B$. microti was similar in $M$. arvalis and $M$. oeconomus, but no positive blood smears were identified among $17 \mathrm{M}$. agrestis (3 Babesia-positive samples by PCR only, Table 2) so the estimated mean abundance was close to zero for this host species. There were no significant differences in mean abundance of $B$. microti in the vole community between the years of study, host sexes and age classes (Table 3).

\section{Vertical transmission of $B$. microti}

\section{Prevalence of $B$. microti in females and dams}

Altogether 117 female voles were trapped, among which 44 were pregnant thus providing 27 litters (embryos and pups) from Babesia-positive females and 17 litters from Babesia-negative mothers for analysis of vertical transmission (Fig. 1, Tables 2, 4 and 5). The overall prevalence of $B$. microti infection in the pregnant females was $61.4 \%$ (27/44). Highest prevalence was in pregnant female $M$. arvalis $(71 \%, 22$ litters from Babesia-positive

Table 1 Wild-caught Microtus voles sampled in 2013-2014

\begin{tabular}{|c|c|c|c|c|c|c|c|c|c|c|}
\hline \multirow{3}{*}{ Vole species } & \multirow[b]{3}{*}{ Sex } & \multicolumn{4}{|c|}{2013} & \multicolumn{4}{|c|}{2014} & \multirow[b]{3}{*}{ TOTAL } \\
\hline & & \multicolumn{4}{|c|}{ Age class } & \multicolumn{4}{|c|}{ Age class } & \\
\hline & & 1 & 2 & 3 & 2013 Total by species & 1 & 2 & 3 & 2014 Total by species & \\
\hline \multirow[t]{3}{*}{ M. agrestis } & 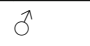 & 0 & 2 & 7 & 14 & 0 & 0 & 1 & 3 & 17 \\
\hline & q & 1 & 2 & 2 & & 0 & 2 & 0 & & \\
\hline & $\hat{o}+q$ & 1 & 4 & 9 & & 0 & 2 & 1 & & \\
\hline \multirow[t]{3}{*}{ M. arvalis } & $\hat{0}$ & 2 & 1 & 17 & 55 & 5 & 1 & 27 & 69 & 124 \\
\hline & q & 5 & 11 & 19 & & 4 & 6 & 26 & & \\
\hline & $\hat{o}+q$ & 7 & 12 & 36 & & 9 & 7 & 53 & & \\
\hline \multirow[t]{3}{*}{ M. oeconomus } & $\hat{0}$ & 0 & 1 & 11 & 19 & 7 & 1 & 17 & 57 & 76 \\
\hline & q & 1 & 3 & 3 & & 2 & 9 & 21 & & \\
\hline & $\hat{o}+q$ & 1 & 4 & 14 & & 9 & 10 & 38 & & \\
\hline Total by age class & & 9 & 20 & 59 & 88 & 18 & 19 & 92 & 129 & 217 \\
\hline
\end{tabular}


Table 2 Prevalence of Babesia microti in three species of wild-caught Microtus voles

\begin{tabular}{|c|c|c|c|c|c|c|c|c|c|c|c|c|c|}
\hline \multirow[t]{2}{*}{ Year } & \multirow[b]{2}{*}{ Infection } & \multicolumn{3}{|c|}{ M. arvalis } & \multicolumn{3}{|c|}{ M. agrestis } & \multicolumn{3}{|c|}{ M. oeconomus } & \multicolumn{3}{|c|}{ Microtus spp. } \\
\hline & & $\pi$ & q & All & $\pi$ & q & All & $\pi$ & q & All & $\hat{0}$ & q & Total \\
\hline \multirow[t]{3}{*}{2013} & $\mathrm{NI}$ & 11 & $18(9)$ & 29 & 7 & $4(2)$ & 11 & 6 & $4(3)$ & 10 & 24 & $26(14)$ & 50 \\
\hline & I & 9 & $17(12)$ & 26 & 2 & $1(1)$ & 3 & 6 & $3(2)$ & 9 & 17 & $21(15)$ & 38 \\
\hline & $\%$ B. microti-infected & 45 & $48.6(57.1)$ & 47.3 & 22.2 & $20(33.3)$ & 21.4 & 50 & $42.9(40.0)$ & 47.4 & 41.5 & $44.7(51.7)$ & 43.2 \\
\hline \multirow[t]{3}{*}{2014} & $\mathrm{Nl}$ & 17 & $22(0)$ & 39 & 1 & $2(0)$ & 3 & 11 & $25(3)$ & 36 & 29 & $49(3)$ & 78 \\
\hline & I & 16 & $14(10)$ & 30 & 0 & $0(0)$ & 0 & 14 & $7(2)$ & 21 & 30 & $21(12)$ & 51 \\
\hline & $\%$ B. microti-infected & 48.5 & $38.9(100)$ & 43.5 & 0 & 0 & 0 & 56 & $21.9(40.0)$ & 36.8 & 50.9 & $30(80)$ & $39.5 \%$ \\
\hline \multirow[t]{3}{*}{$\Sigma$} & $\mathrm{NI}$ & 28 & $40(9)$ & 68 & 8 & $6(2)$ & 14 & 17 & $29(6)$ & 46 & 53 & $75(17)$ & 128 \\
\hline & । & 25 & $31(22)$ & 56 & 2 & $1(1)$ & 3 & 20 & $10(4)$ & 30 & 47 & $42(27)$ & 89 \\
\hline & $\%$ B. microti-infected & 47.2 & $43.7(71)$ & 45.2 & 20 & $14.3(33.3)$ & 17.7 & 54.1 & $25.6(40.0)$ & 39.5 & 47 & $35.9(61.4)$ & 41.0 \\
\hline
\end{tabular}

Abbreviations: $N$ I uninfected, I infected, in parentheses - no. of pregnant females

females), $40 \%$ in pregnant female $M$. oeconomus (4 litters from Babesia-positive females) but only one female of 3 pregnant $M$. agrestis was found to be Babesia-positive (2013, 33.3\%, 1 litter). There were significant differences in the prevalence of $B$. microti in pregnant females between host species and years of study (year $\times$ host species $\times$ Babesia infection: $X^{2}=12.10, \quad d f=2, \quad P=0.002$ ) (Table 2). All pregnant $M$. arvalis females trapped in 2014 were Babesia-positive (100\%), in comparison with 57\% Babesia-positive pregnant voles in 2013, but there were no differences in the prevalence of $B$. microti

Table 3 Abundance of Babesia microti (mean number of infected red blood cells (iRBC)/200 fields of vision \pm standard error, SE) in wild-caught voles

\begin{tabular}{llll}
\hline & Year & & \\
\cline { 2 - 3 } Species & 2013 & 2014 & Total \\
\hline M. arvalis & & & \\
Males & $58.38 \pm 54.87$ & $15.94 \pm 48.85$ & $37.16 \pm 36.73$ \\
Females & $10.32 \pm 25.73$ & $2.10 \pm 30.68$ & $6.21 \pm 20.02$ \\
All & $34.35 \pm 30.30$ & $9.02 \pm 28.84$ & $21.68 \pm 20.92$ \\
M. oeconomus & & & \\
Males & $32.32 \pm 68.77$ & $38.35 \pm 48.12$ & $35.93 \pm 39.88$ \\
Females & $0.00 \pm 56.67$ & $6.64 \pm 35.63$ & $3.32 \pm 33.47$ \\
All & $12.93 \pm 43.74$ & $22.49 \pm 29.94$ & $18.14 \pm 25.73$ \\
Microtus spp & & & \\
Males & $47.95 \pm 44.12$ & $27.14 \pm 35.26$ & $36.60 \pm 27.78$ \\
Females & $5.16 \pm 32.00$ & $4.37 \pm 24.17$ & $4.76 \pm 20.05$ \\
Overall mean & $24.61 \pm 26.59$ & $15.75 \pm 21.37$ & $19.99 \pm 16.91$ \\
Microtus spp. ${ }^{\mathrm{b}}$ & & & \\
Males & $34.25 \pm 34.16$ & $23.27 \pm 34.89$ & $28.76 \pm 24.41$ \\
Females & $3.44 \pm 29.30$ & $3.74 \pm 24.14$ & $3.57 \pm 19.58$ \\
Overall mean & $16.920 \pm 22.25$ & $13.50 \pm 21.22$ & $15.33 \pm 15.45$ \\
\hline
\end{tabular}

${ }^{\mathrm{a}}$ Mean no. of iRBC/200 fields for combined $M$. arvalis and $M$. oeconomus ${ }^{\mathrm{b}}$ Mean no. of iRBC/200 fields for three vole species including 17 individuals of M. agrestis between years of study in pregnant female root voles (Table 2).

Of the 44 pregnant females, 11 were kept in captivity until pup delivery, and these provided 10 litters from Babesia-positive females (host species and litter size provided in Table 5) and 1 litter (6 pups) from a Babesianegative $M$. oeconomus female (Fig. 1). Reliable analysis of the prevalence of infections in embryos was possible for 113 embryos from another 20 litters [14 litters from Babesia-positive females (Fig. 1, Table 4) and 6 litters from Babesia-negative females]. These embryos were of an appropriate size to enable autopsy and isolation of organs (heart with lungs, for all samples). In the remaining 13 cases of pregnancy (3 Babesia-positive females and 10 Babesia-negative females), pregnancies were at an early stage and no reliable isolation of embryos' organs could be carried out.

\section{Detection of B. microti in pregnant females and embryos (2013 and 2014)}

Prevalence of $B$. microti infection as determined by PCR and nested PCR among the 113 embryos of the 20 terminally euthanized females was $70 \%$ (14 litters and 75 embryos from Babesia-positive females and 6 litters and 38 embryos from Babesia-negative females). Among Babesia-positive pregnant females, 11 were M. arvalis, two M. oeconomus and one M. agrestis (Fig. 1, Table 4). Babesia-positive tissues (heart and lungs) in embryos were found in $85.7 \%(12 / 14)$ of these litters. No $B$. microti DNA was detected in 38 embryos of the 6 Babesianegative females $(2 \mathrm{M}$. arvalis, $3 \mathrm{M}$. oeconomus, $1 \mathrm{M}$. agrestis), in comparison to 61 positive of 75 embryos recovered from 14 Babesia-positive females (81.3\%) (Fisher's exact test, $P<0.0001$ ). In addition to the Babesia positive heart and lung samples, the DNA of $B$. microti was detected also in liver tissues in 4 out of 5 tested embryos (M. arvalis). 
Table 4 Evidence for vertical transmission and genotype identity of B. microti in embryos isolated from female voles in 2013 and 2014

\begin{tabular}{|c|c|c|c|c|c|c|}
\hline \multirow{2}{*}{$\begin{array}{l}\text { ID of pregnant } \\
\text { female }\end{array}$} & \multirow[t]{2}{*}{ Host species } & \multirow{2}{*}{$\begin{array}{l}\text { No. of embryos } \\
\text { in litter }\end{array}$} & \multirow{2}{*}{$\begin{array}{l}\text { No. of embryos infected } \\
\text { with B. microti in the litter }\end{array}$} & \multirow{2}{*}{$\begin{array}{l}\% \text { of infected } \\
\text { embryos }\end{array}$} & \multicolumn{2}{|l|}{ B. microti genotype } \\
\hline & & & & & In positive female & $\begin{array}{l}\text { In embryos } \\
\text { (no. of genotyped embryos) }\end{array}$ \\
\hline $2013 / 3$ & M. arvalis & 7 & 7 & 100 & IRU 1 & IRU 1 (3) \\
\hline 2013/15 & M. arvalis & 4 & 4 & 100 & $\operatorname{IRU} 1$ & $\operatorname{IRU} 2$ (3) \\
\hline $2013 / 20$ & M. arvalis & 5 & 5 & 100 & IRU 1 & IRU 2 (2) \\
\hline $2013 / 21$ & M. arvalis & 6 & 6 & 100 & IRU 1 & IRU 2 (3) \\
\hline $2013 / 24$ & M. agrestis & 7 & 0 & 0 & IRU 1 & nd \\
\hline $2013 / 37$ & M. arvalis & 5 & 5 & 100 & IRU 1 & IRU 2 (2) \\
\hline $2013 / 41$ & M. arvalis & 6 & 6 & 100 & nd & IRU 2 (3) \\
\hline $2013 / 47$ & M. arvalis & 2 & 2 & 100 & IRU 1 & IRU 1 (1) \\
\hline $2013 / 52$ & M. arvalis & 6 & 6 & 100 & IRU 2 & IRU 1 (1) and IRU 2 (2) \\
\hline $2013 / 53$ & M. arvalis & 6 & 6 & 100 & nd & IRU 2 (1) \\
\hline 2013/63 & M. oeconomus & 5 & 5 & 100 & IRU 2 & IRU 2 (1) \\
\hline 2013/72 & M. arvalis & 6 & 6 & 100 & IRU 1 & IRU 1 (2) \\
\hline $2014 / 44$ & M. oeconomus & 6 & 0 & 0 & IRU 1 & nd \\
\hline $2014 / 155$ & M. arvalis & 4 & 3 & 75 & nd & IRU 2 (3) \\
\hline Total & & 75 & $61(81.3 \%)$ & $\begin{array}{l}\text { Litters positive } \\
12 / 14(85.7 \%)\end{array}$ & $\begin{array}{l}9 \times \operatorname{IRU} 1 \\
2 \times \operatorname{IRU} 2\end{array}$ & $\begin{array}{l}7 \times \operatorname{IRU} 1 \\
20 \times \operatorname{IRU} 2\end{array}$ \\
\hline
\end{tabular}

Abbreviation: $n d$ not done

Among the three host species, no B. microti DNA was detected in 7 embryos from 1 litter of one Babesia-positive $M$. agrestis female, in comparison to $56 / 57$ positive embryos from $11 \mathrm{M}$. arvalis females (vertical transmission confirmed in all litters with overall $98 \%$ embryos positive for B. microti, and between $75-100 \%$ success of transmission per litter; Table 4). Among two Babesia-positive $M$. oeconomus females, $B$. microti DNA was detected in all 5 embryos from one litter and in none of 6 embryos of a second litter, giving in total $50 \%$ success of vertical transmission for litters and $46 \%$ of Babesia-positive embryos from infected females (Table 4). In summary, B. microti DNA was detected in 0, 50 and $100 \%$ of the litters of Babesia-positive M. agrestis, M. oeconomus and $M$. arvalis females, respectively. Among these litters, 0, 46 and $98 \%$ of embryos were infected with B. microti for Babesia-positive $M$. agrestis, $M$. oeconomus and $M$. arvalis females, respectively, and these differences in

Table 5 Evidence for vertical transmission and genotypes of B. microti in pups delivered by female voles captured in 2014

\begin{tabular}{|c|c|c|c|c|c|c|}
\hline \multirow{2}{*}{$\begin{array}{l}\text { ID of pregnant } \\
\text { female }\end{array}$} & \multirow[t]{2}{*}{ Host species } & \multirow{2}{*}{$\begin{array}{l}\text { No. of pups } \\
\text { in a litter }\end{array}$} & \multirow{2}{*}{$\begin{array}{l}\text { No. of embryos infected } \\
\text { with B. microti in the litter }\end{array}$} & \multirow[t]{2}{*}{$\%$ of infected pups } & \multicolumn{2}{|c|}{ B. microti genotype } \\
\hline & & & & & In positive dam & $\begin{array}{l}\text { No. of pups } \\
\text { (no. of genotyped pups) }\end{array}$ \\
\hline $2014 / 25$ & M. arvalis & 6 & 5 & 83 & IRU 1 & $\operatorname{IRU} 1(1)$ and IRU 2 (1) \\
\hline $2014 / 34$ & M. arvalis & 5 & 4 & 80 & IRU 2 & IRU 1 (2) \\
\hline $2014 / 59$ & M. arvalis & 5 & 5 & 100 & nd & IRU 1 (1) and IRU 2 (1) \\
\hline $2014 / 65$ & M. arvalis & 6 & 6 & 100 & IRU 1 & IRU 1 (1) and IRU 2 (1) \\
\hline 2014/77 & M. oeconomus & 6 & 5 & 83 & IRU 2 & IRU 2 (2) \\
\hline 2014/107 & M. arvalis & $6^{a}$ & 0 & 0 & IRU 1 & nd \\
\hline 2014/112 & M. arvalis & 5 & 5 & 100 & nd & $\operatorname{IRU} 2$ (1) \\
\hline $2014 / 126$ & M. arvalis & 7 & 4 & 57 & nd & IRU 2 (1) \\
\hline 2014/130 & M. arvalis & 4 & 3 & 75 & nd & IRU 2 (3) \\
\hline 2014/131 & M. arvalis & 6 & 3 & 50 & nd & IRU 2 (2) \\
\hline In total & & 56 & $40(71.4 \%)$ & $\begin{array}{l}\text { Litters positive } \\
9 / 10(90 \%)\end{array}$ & $\begin{array}{l}3 \times \operatorname{RU} 1 \\
2 \times \operatorname{RQ} 2\end{array}$ & $\begin{array}{l}5 \times \mathbb{R} U 1 \\
12 \times \mathbb{R} U 2\end{array}$ \\
\hline
\end{tabular}


the success of vertical transmission of $B$. microti were statistically significant (host species $\times$ Babesia presence/ absence in embryos: $\left.\chi^{2}=51.28, d f=2, P<0.0001\right)$.

\section{Detection of B. microti in dams and pups maintained in vector-free conditions (2014)}

In the second year of the study, 11 pregnant females ( $9 \mathrm{M}$. arvalis and $2 \mathrm{M}$. oeconomus), deprived of all ectoparasites, were kept in our animal house until they had given birth and weaned their pups $(n=62)$. Babesia microti DNA was detected in all $M$. arvalis dams and in one of two M. oeconomus dams (Table 5). No B. microti DNA was detected in 6 pups delivered by a Babesianegative $M$. oeconomus dam, in comparison to 40/56 (71.4\%) positive pups delivered by 10 Babesia-positive dams. In one litter from a Babesia-positive M. oeconomus dam, 5 of 6 pups were positive (83\%), in comparison to $70 \%$ (35/50) positive pups from 9 Babesia-positive $M$. arvalis dams (Table 5) (difference not significant, NS). Among 9 litters from $M$. arvalis dams, Babesia-positive pups were found in 8 litters (8/9 litters i.e. $89 \%$ of success in litters) and among positive litters, the percentage of Babesia-positive pups varied in the range 50-100\% (Table 5).

The percentage of Babesia-positive pups in a litter was negatively correlated with litter size $\left(r_{S}=-0.661, P=0.052\right)$ (Table 5). There was no significant difference between male and female pups born from infected dams: $86.2 \%$ of males and $71.4 \%$ of females were infected with $B$. microti.

When we analyzed data on embryos and pups together, the significant factors influencing Babesia infection in offspring were: host species (host species $\times$ Babesia presence/absence in embryos/pups: $\chi^{2}=46.43$, $d f=2, P<0.0001)$ with the highest success of vertical transmission in $M$. arvalis as described above; infection in the mother $\left(\chi^{2}=84.30, d f=1, P<0.0001\right)$ with no infections in the offspring of Babesia-negative females and a high rate of congenital infections in offspring of Babesia-positive females (Tables 4 and 5); and year of study (year $\times$ Babesia presence/absence in embryos/ pups: $\left.\chi^{2}=29.99, d f=1, P<0.0001\right)$. Interestingly, a higher percentage of Babesia-positive offspring was obtained in the first year of the study when we focused on embryos, in comparison to 2014, when the focus was on pups (Tables 4 and 5).

\section{Influence of congenitally acquired B. microti infection on litter size, body mass and survival of pups}

Two litters (6 pups of $M$. arvalis and 6 pups of $M$. oeconomus) died 1-2 days after birth. All these pups were Babesia-negative by PCR, although one litter was delivered by a Babesia-positive dam (M. arvalis, ID 2014/107; Table 5). The other litter was delivered by the only one Babesia-negative M. oeconomus dam. All the other pups delivered by 9 Babesia-positive dams (40 Babesia-positive and 10 Babesia-negative pups; Table 5) survived until the end of the experiment. Thus the mortality of pups was $0 \%$ among Babesia-positive and $54.5 \%(12 / 22)$ among Babesia-negative pups and this difference was significant (alive/dead pup $\times$ Babesia presence/absence: $\left.\chi^{2}=30.61, d f=1, P<0.0001\right)$.

The mean litter size for all 11 dams was $5.85 \pm 0.43$ and was similar among $M$. arvalis and $M$. oeconomus dams (5.56 \pm 0.29 and $6.0 \pm 0.62 ; \mathrm{NS})$. The effect of Babesia infection in the dam on the litter size could not be reliably analyzed as there was only one litter from a Babesia-negative dam (with 6 pups) and the mean litter size for Babesia-positive dams was $5.78 \pm 0.47$ (NS).

The mean body mass of $M$. oeconomus pups at age of 3 weeks was significantly higher than for $M$. arvalis pups: $17.86 \pm 1.09 \mathrm{~g}$ and $15.13 \pm 0.46 \mathrm{~g}$, respectively (main effect of host species on body mass of pups: $F_{(1,49)}=4.78 ; P$ $=0.03)$. Male pups of $M$. arvalis were slightly heavier $(15.80 \pm 0.66 \mathrm{~g})$ than females $(14.45 \pm 0.64 \mathrm{~g})$, but for $M$. oeconomus pups the mean weight of pups was closer: $17.75 \pm 1.71 \mathrm{~g}$ for males and $17.92 \pm 1.40 \mathrm{~g}$ for females (NS). The mean weight was almost identical for Babesiapositive pups and Babesia-negative pups (16.59 $\pm 0.59 \mathrm{~g}$ and $15.91 \pm 0.97 \mathrm{~g})$ (NS).

The abundance of $B$. microti was calculated on the basis of microscopical observation of blood smears of $44 M$. arvalis and 6 of $M$. oeconomus pups. The mean abundance of $B$. microti in blood smears collected from offspring of infected dams was $0.54 \pm 0.11$, but this was twice as high in $M$. oeconomus compared with $M$. arvalis pups $\left(0.75 \pm 0.21\right.$ and $0.32 \pm 0.74$, respectively; $F_{(1,49)}=$ 3.78, $P=0.06)$.

\section{Genotyping of B. microti isolates from wild-caught voles and congenitally acquired infections}

Altogether 97 (73 M. arvalis, $22 \mathrm{M}$. oeconomus and 2 $M$. agrestis) Babesia sequences were obtained. Among these, 53 were derived from naturally infected voles, including pregnant females and dams (32 M. arvalis, 19 $M$. oeconomus and $2 M$. agrestis) and 44 were obtained from embryos or pups.

Alignment of the sequences revealed that two main $B$. microti genotypes were found in wild-caught voles, pregnant females and embryos, dams and their pups: one genotype was most similar (98-100\% of similarity) to $B$. microti IRU1 isolate (KC470048), closely related to the pathogenic Jena strain (EF413181) isolated from human blood [31] and the second genotype was most similar (98-100\%) to the B. microti IRU2 isolate (KC470049), closely related to the non-pathogenic Munich strain (AY789075), first isolated from the house mouse Mus musculus by Tsuji and Ishihara (2001, published on GenBank only). Lower similarity for several sequences 
was the result of some non-specific background amplification of DNA. Both IRU1 and IRU2 genotypes of $B$. microti have been detected previously in $I$. ricinus ticks in our earlier studies in the same region of Poland [10].

The IRU1 (Jena-like) B. microti genotype was dominant among wild-caught voles $(49 / 53$; 92\%), pregnant females $(81.8 \%)$ and dams $(60 \%)$ and altogether was identified in $62.9 \%(61 / 97)$ of the sequenced isolates. The IRU2 (Munich-like) genotype was dominant among positive embryos $(74.1 \%)$ and pups $(70.6 \%)$ and altogether was identified in $37.1 \%(36 / 97)$ of the Babesia isolates (Tables 4 and 5).

Among the $B$. microti sequences obtained from wildcaught voles, 32 were from $M$. arvalis, 19 from M. oeconomus and 2 from $M$. agrestis. The B. microti IRU1 genotype (Jena-like) was identified in $94 \%$ of sequences derived from $M$. arvalis (10 from males and 20 from females), in $89 \%$ of sequences derived from $M$. oeconomus (13 from males, 4 from females) and in both sequences from $M$. agrestis ( 1 from a male and 1 from a female vole). The IRU2 genotype of $B$. microti (Munich-like) was identified in 4 isolates from females $(2 \mathrm{M}$. arvalis and 2 M. oeconomus).

The final step of our study on vertical transmission was to determine the $B$. microti genotype infecting females/dams and their embryos/pups. We were able to sequence eleven PCR products from pregnant females (Table 4: 8 from $M$. arvalis, 2 from $M$. oeconomus and 1 from $M$. agrestis) and selected 27 embryos recovered from these females. In 3 cases the genotypes of $B$. microti identified in the female and her offspring were identical (IRU1 genotype) and in one case either the IRU1 or IRU2 genotypes were found in isolates from offspring. In 4 cases the $B$. microti genotype identified in the female was different from the genotype identified in the embryos (Table 4: the B. microti IRU1 genotype in females but IRU2 in embryos). Thus, the dominant $B$. microti genotype identified in pregnant females was IRU1 (9/11; 81.8\%). In embryos, the IRU2 genotype was identified more often $(20 / 27 ; 74.1 \%)$. Interestingly, for two females infected with the B. microti IRU1 (Jena-like) genotype strain $(1 M$. oeconomus and $1 M$. agrestis) no evidence of vertical transmission in embryos was found (all embryos were Babesia-negative).

In 2014 we were able to sequence PCR products from 5 dams ( $4 M$. arvalis and $1 M$. oeconomus) and from selected pups of 9 dams (Table 5). In one case the genotype of $B$. microti identified in the dam and her two pups was identical (IRU2 genotype) and in 2 cases either the IRU1 or IRU2 genotypes were found in isolates from pups. In one case the $B$. microti genotype identified in the dam was different from the genotype identified in the pups (Table 5: B. microti IRU2 genotype in dam but the IRU1 genotype in two pups). In four other litters, where the $B$. microti genotype in the dams could not be determined, the IRU2 genotype was identified in pups, and in one litter again both B. microti genotypes were found (Table 5). Thus, the dominant $B$. microti genotype identified in dams was IRU1 $(3 / 5,60 \%)$ whereas among pups, the IRU2 genotype was more common (12/17; $70.6 \%)$.

\section{Discussion}

In this study we reported a high prevalence of B. microti in a Microtus spp. community in Poland and provided evidence in support of the idea that, in two main host species, $M$. arvalis and $M$. oeconomus, high prevalence can be partially maintained by a high rate of vertical transmission from naturally infected female voles to their offspring. We also reported a complex circulation of two main rodent $B$. microti genotypes, the zoonotic Jena-like (IRU1) and the enzoonotic Munich-like (IRU2) genotypes, in the community of three Microtus species.

Although the present study focused primarily on the occurrence of vertical transmission of $B$. microti in the three vole species, it also provided novel data to complement our interest in the long-term dynamics of $B$. microti at our study sites in the Mazury Lake District. The first study on $B$. microti in voles was carried out in 1997-2000 [1] and focused on M. arvalis; then in 20042006 the second study incorporated $M$. arvalis and $M$. oeconomus populations [2,34] and finally, in the present paper we report on B. microti prevalence in the community of three vole species. Overall prevalence of $B$. microti in this period of 17 years was lowest in the first 4 years $(9 \%$; $[1])$ and was similar in two latter surveys (32-35\% [2] versus $41 \%$ in the present report). However, the markedly lower prevalence of $B$. microti in $M$. arvalis in the first study is probably attributable mostly to a different sampling strategy and detection techniques - the study was spread over three seasons of the year (spring, summer and autumn) and based solely on microscopical observation of blood smears, which is a far less sensitive method for the detection of chronic infections of $B$. microti in comparison to molecular techniques, as demonstrated in the experimental study by Welc-Faleciak et al. [35] Building on this first study, where $B$. microti infections in voles were apparently seasonal, with maximum prevalence in summer, the two latter studies were carried out only in summer months (August and early September) and employed molecular techniques (PCRs) for detection of the parasite, thus providing more comparable data over the period of ten years from 2004 to 2014. Prevalence of $B$. microti was highest in $M$. arvalis in this period (35-45\%) and only slightly lower in $M$. oeconomus (32-40\%). A similar pattern was observed in abundance of $B$. microti. Interestingly, both parameters were lowest in the third species, $M$. agrestis, which was 
sampled and studied only in 2013-2014. This species is rarely reported from our study sites in the Mazury Lake District [36] and as our data show, this is a species of much lower significance as a reservoir host of $B$. microti. Interestingly, over the long-term, there were a few years when $B$. microti prevalence in $M$. arvalis was extremely high, as for example exceeding $20-50 \%$ across three seasons in 1998 or $70 \%$ in the summer months of 2005 [1, 34]. Our finding that $M$. arvalis and $M$. oeconomus are the principal reservoir hosts of $B$. microti is supported by other studies from north-eastern Poland and from other regions of central Europe [37-42]. In Poland, prevalence has been reported in the range of $9-72 \%$ for $M$. arvalis and $8-50 \%$ for $M$. oeconomus $[4,37,38]$ and within the range of $0.6-14 \%$ in other countries [39-42]. Surveys in the UK, where M. agrestis is the only species of the genus Microtus and is reported as the main host of $B$. microti, have reported high prevalence values within the range of $22-30 \%$, higher than in our study sites [43-46]. High prevalence of B. microti in M. agrestis has been reported also in Southern Poland $(50 \%$ in Katowice; [37]), Germany (38\%; [47]), Austria (31\%; [48]) and Russia (52\%, [14]). The overall prevalence in the community of voles in the current study was similar to prevalence in Omsk region, Russia (31.6\%, [14]).

We found intriguing the generally low infestation of $I$. ricinus ticks, hosts of B. microti, on Microtus spp. and the high prevalence of the parasite in voles, in contrast to the high infestation of $I$. ricinus ticks on woodland rodents and the generally low prevalence of $B$. microti in the latter hosts. Therefore we tested the hypothesis that high prevalence of B. microti in Microtus hosts maybe achieved by vector independent vertical transmission of parasites between females and their offspring. Quite clearly our observations, whether based on pregnant females-embryos or dams-pups, support our hypothesis, both revealing a high rate of vertical transmission in $M$. arvalis and $M$. oeconomus. Altogether $81 \%$ of embryos from Babesia-positive females and $71 \%$ of pups from Babesia-positive dams were Babesia-positive. This rate of Babesia-positive offspring derived from Babesiapositive female voles may be compared with an overall prevalence of B. microti in juvenile voles of $19 \%$ (in juveniles of all species combined; $25 \%$ of juveniles of $M$. arvalis). However, to enable a more meaningful comparison, estimation of Babesia-positive offspring should include also Babesia-negative offspring of Babesianegative females. Combing these data, we obtain a value of $58 \%$ for the prevalence of Babesia in the offspring in the F1 generation (2013 and 2014), which is higher than the prevalence observed in wild-caught juvenile voles. This difference may be explained by two mechanisms - the progressive loss of congenitally acquired infection with age (which explains also the difference between the percentages of Babesia-positive embryos and pups) and/or faster loss of infected offspring under natural conditions, i.e. by predation. To support the latter hypothesis (on the negative impact of congenitally acquired Babesia infection), we compared selected parameters between Babesia-positive and $\mathrm{Ba}$ besia-negative litters (litter size) and pups (i.e. survival rate, mean body weight). However, no evidence was found to support this hypothesis, as mean litter size and body weight were almost identical in both groups. In fact, in contrast to our expectations, the survival rate over three weeks after birth was lower among Babesianegative pups. These findings support the 'balancing strategy hypothesis' [49]. The balancing strategy hypothesis proposes that long-term co-evolution of parasite-host interactions results in a 'balanced' system, with a low negative impact of parasites on the host population, low pathogenicity and mortality enabling simultaneous propagation of both parasite and host without epidemic periods that are characteristic in many viruses and bacteria systems which follow an 'opposing strategy'. The very low parasitaemia found in the pups with congenitally acquired $B$. microti infection (1-5 iRBC/200 fields of vision) in comparison to wildcaught voles (mean19.99 $\pm 16.91 \quad \mathrm{iRBC} / 200$ fields) supports this hypothesis, together with the known long-term survival of $B$. microti infection in rodent hosts under natural and experimental conditions $[15,35]$. Thus Babesia may be considered to be a master of a balancing strategy, together with Plasmodium falciparum, given as the example by Wenk \& Renz [49].

The occurrence of Babesia-positive litters and Babesiapositive offspring was higher in $M$. arvalis than in $M$. oeconomus, reflecting a slightly but permanently higher prevalence of $B$. microt $i$ in common voles throughout the 17-year-long period of field studies in the Mazury Lake District $[1,2,50]$. Interestingly, we observed lower success of vertical transmission (\% of Babesia-positive) in larger litters of pups in comparison to smaller, and this may represent a 'dilution effect', described for some parasite species in high-density populations of their hosts [51].

The final steps to complete the study on vertical transmission were to identify the genotypes of $B$. microti in the community of voles, in pairs of females and their offspring, and to determine the prevalence of zoonotic to non-zoonotic strains in both mothers and their offspring. In the event, a complex picture emerged, involving two common strains of $B$. microti. Interestingly, both $B$. microti strains, the zoonotic Jena-like (IRU1) and nonpathogenic Munich-like (IRU2) genotypes were found in both wild-caught voles and the captive-maintained female-offspring group. The Jena-like strain was dominant among wild-caught voles, including pregnant females and dams. These results correspond to our earlier results during the period 2004-2006 [32]. In 2004, all the 
B. microti isolates that were sequenced were identified as the Munich-like strain and this strain was involved in an 'outbreak' of B. microti infection in M. arvalis, with prevalence exceeding 70\% [32]. In 2005 again this strain was dominant, with a low percentage of isolates identified as the Jena-like strain, but in 2006 the pattern was reversed with all genotyped isolates identified as the Jena-like strain. Also in Russia, the enzootic B. microti strain (Munich) and the zoonotic strain (US/Gray/Jena strain) have been fund to be sympatric in different study sites, but with dominance by one or the other strain depending on the location $[14,52,53]$. The dominant strain in the region of Omsk was B. microti Munich with a dominance of $93 \%$ [14], in contrast to the $92 \%$ for $B$. microti IRU1/Jena-like stain in our study. However, in the present study the picture appears to be more complex because of the occurrence of different strains in the female-offspring combinations and also the detection of both strains in a single litter. Our results show that mixed infections of both genotypes can occur in adult voles, with the Jena-like (IRU1) genotype more 'detectable' or dominant in adult voles and the Munich-like (IRU2) genotype more detectable or dominant in offspring. One possibility is that the Munich-like strain has a better capacity for vertical transmission and propagation in younger voles, while the Jena-like strain may be better at maintaining a chronic infection in voles but has a lower success in vertical transmission (Tables 4 and 5). These proposed contrasting biological traits of the B. microti IRU1 and IRU2 strains may be responsible for the dynamic pattern in the proportion of each strain observed in our study sites throughout the years over which we have monitored the host populations. However, the possibility that the two strains differ in pathogenicity requires further study, especially regarding the zoonotic significance of the Jena-like strain.

\section{Conclusions}

A high rate of vertical transmission of two main genotypes of $B$. microti has been confirmed in two species of naturally infected voles, $M$. arvalis and $M$. oeconomus, resulting in an overall high prevalence of infection in a community of Microtus spp. voles from nort-eastern Poland.

\section{Acknowledgments}

Not applicable.

\section{Funding}

The study was financially supported by the National Science Centre, grants OPUS no. 2014/13B/NZ7/02348 (MB) and 2011/03/B/NZ8/02212 (AB).

\section{Availability of data and materials}

The datasets supporting the conclusions of this article are included within the article. Raw data will be made available upon a request. Representative sequences are submitted to the GenBank database under accession numbers KC470048.1 (IRU 1) and KC470049 (IRU2).

\section{Authors' contributions}

$\mathrm{KT}$ and $\mathrm{AB}$ designed the study, performed laboratory and statistical analyses. $M B$ and RWF participated in the detection and genotyping of Babesia. KT, $A B, M A, D D, M G$ and JMB participated in field works and drafted the manuscript. All authors read and approved the final manuscript.

\section{Competing interests}

The authors declare that they have no competing interests.

\section{Consent for publication}

Not applicable.

\section{Ethics approval}

All of the procedures were conducted with the approval of the First Ethics Committee for Animal Experimentation in Poland (ethical license numbers: 148/2011 and 406/2013) according to the principles governing experimental conditions and care of laboratory animals required by the European Union and the Polish Law on Animal Protection.

\section{Author details}

${ }^{1}$ Department of Parasitology, Institute of Zoology, Faculty of Biology, University of Warsaw, 1 Miecznikowa Street, 02-096 Warsaw, Poland.

${ }^{2}$ Department of Parasitology and Invasive Diseases, Faculty of Veterinary Medicine, University of Life Sciences in Lublin, 12 Akademicka Street, 20-950 Lublin, Poland. ${ }^{3}$ School of Life Sciences, University of Nottingham, University Park, Nottingham NG7 2RD, UK.

Received: 28 July 2016 Accepted: 27 January 2017

Published online: 06 February 2017

\section{References}

1. Pawelczyk A, Bajer A, Behnke JM, Gilbert FS, Sinski E. Factors affecting the component community structure of haemoparasites in common voles (Microtus arvalis) from the Mazury Lake District region of Poland. Parasitol Res. 2004;92(4):270-84.

2. Welc-Falęciak R, Bajer A, Behnke JM, Siński E. Effects of host diversity and the community composition of hard ticks (Ixodidae) on Babesia microti infection. Int J Med Microbiol. 2008;298:235-42.

3. Karbowiak G. Zoonotic reservoir of Babesia microti in Poland. Pol J Microbiol. 2004;53(Suppl):61-5

4. Sinski E, Bajer A, Welc R, Pawelczyk A, Ogrzewalska M, Behnke JM. Babesia microti: prevalence in wild rodents and lxodes ricinus ticks from the Mazury Lakes District of North-Eastern Poland. Int J Med Microbiol. 2006;296 Suppl 40:137-43.

5. Gray J, Zintl A, Hildebrandt A, Hunfeld KP, Weiss L. Zoonotic babesiosis: overview of the disease and novel aspects of pathogen identity. Ticks Tick Borne Dis. 2010;1(1):3-10.

6. Vannier E, Krause PJ. Human babesiosis. N Engl J Med. 2012;366(25):2397-407.

7. Haselbarth K, Tenter AM, Brade V, Krieger G, Hunfeld KP. First case of human babesiosis in Germany - Clinical presentation and molecular characterisation of the pathogen. Int J Med Microbiol. 2007;297(3):197-204.

8. Meer-Scherrer L, Adelson M, Mordechai E, Lottaz B, Tilton R. Babesia microti infection in Europe. Curr Microbiol. 2004;48(6):435-7.

9. Welc-Faleciak R, Pawelczyk A, Radkowski M, Pancewicz SA, Zajkowska J, Sinski E. First report of two asymptomatic cases of human infection with Babesia microti (Franca, 1910) in Poland. Ann Agric Environ Med. 2015;22(1):51-4.

10. Welc-Faleciak R, Bajer A, Paziewska-Harris A, Baumann-Popczyk A, Sinski E. Diversity of Babesia in Ixodes ricinus ticks in Poland. Adv Med Sci. 2012; 57(2):364-9.

11. Katargina O, Geller J, Vasilenko V, Kuznetsova T, Jarvekulg L, Vene S, et al. Detection and characterization of Babesia species in Ixodes ticks in Estonia. Vector Borne Zoonotic Dis. 2011;11(7):923-8.

12. Wojcik-Fatla A, Cisak E, Chmielewska-Badora J, Zwolinski J, Buczek A, Dutkiewicz J. Prevalence of Babesia microti in Ixodes ricinus ticks from Lublin region (eastern Poland). Ann Agric Environ Med. 2006;13(2):319-22.

13. Paziewska A, Zwolinska L, Harris PD, Bajer A, Sinski E. Utilisation of rodent species by larvae and nymphs of hard ticks (Ixodidae) in two habitats in NE Poland. Exp Appl Acarol. 2010;50(1):79-91.

14. Rar V, Yakimenko V, Makenov M, Tikunov A, Epikhina T, Tancev A, et al. High prevalence of Babesia microti 'Munich' type in small mammals from an Ixodes persulcatus/Ixodes trianguliceps sympatric area in the Omsk region, Russia. Parasitol Res. 2016. doi:10.1007/s00436-016-5128-9. 
15. Bednarska M, Bajer A, Drozdowska A, Mierzejewska EJ, Tolkacz K, Welc-Faleciak R. Vertical transmission of Babesia microti in BALB/C mice: preliminary report. PLoS One. 2015;10(9):e0137731. doi:10.1371/journal.pone.0137731.

16. Fukumoto S, Suzuki H, Igarashi I, Xuan X. Fatal experimental transplacental Babesia gibsoni infections in dogs. Int J Parasitol. 2005;35(9):1031-5.

17. Mierzejewska EJ, Welc-Faleciak R, Bednarska M, Rodo A, Bajer A. The first evidence for vertical transmission of Babesia canis in a litter of Central Asian Shepherd dogs. Ann Agric Environ Med. 2014;21(3):500-3.

18. Adaszek L, Obara-Galek J, Piech T, Winiarczyk M, Kalinowski M, Winiarczyk S. Possible vertical transmission of Babesia canis canis from a bitch to her puppies: a case report. Vet Med - Czech. 2016;61:263-6.

19. Esernio-Jenssen D, Scimeca PG, Benach JL, Tenenbaum MJ. Transplacental/ perinatal babesiosis. J Pediatr. 1987;110(4):570-2.

20. Joseph JT, Purtill K, Wong SJ, Munoz J, Teal A, Madison-Antenucci S, et al. Vertical transmission of Babesia microti, United States. Emerg Infect Dis. 2012;18(8):1318-21.

21. New DL, Quinn JB, Qureshi MZ, Sigler SJ. Vertically transmitted babesiosis. J Pediatr. 1997;131(1 Pt 1):163-4.

22. Bajer A, Bednarska M, Pawelczyk A, Behnke JM, Gilbert FS, Sinski E. Prevalence and abundance of Cryptosporidium parvum and Giardia spp. in wild rural rodents from the Mazury Lake District region of Poland. Parasitology. 2002;125(Pt 1):21-34.

23. Pucek Z. Keys to vertebrates of Poland. Mammals. Warszawa: PWN; 1981.

24. Bonnet $\mathrm{S}$, Jouglin M, L'Hostis M, Chauvin A. Babesia sp. EU1 from roe deer and transmission within Ixodes ricinus. Emerg Infect Dis. 2007;13(8):1208-10.

25. Bajer A, Alsarraf M, Bednarska M, Mohallal EM, Mierzejewska EJ, BehnkeBorowczyk J, et al. Babesia behnkei sp. nov., a novel Babesia species infecting isolated populations of Wagner's gerbil, Dipodillus dasyurus, from the Sinai Mountains, Egypt. Parasit Vectors. 2014;7:572. doi: 10.1186/s13071014-0572-9.

26. Bajer A, Welc-Faleciak R, Bednarska M, Alsarraf M, Behnke-Borowczyk J, Sinski $E$, et al. Long-term spatiotemporal stability and dynamic changes in the haemoparasite community of bank voles (Myodes glareolus) in NE Poland. Microb Ecol. 2014;68(2):196-211.

27. Bajer A, Rodo A, Mierzejewska EJ, Tolkacz K, Welc-Faleciak R. The prevalence of Dirofilaria repens in cats, healthy dogs and dogs with concurrent babesiosis in an expansion zone in central Europe. BMC Vet Res. 2016;12(1): 183. doi:10.1186/s12917-016-0816-3.

28. Tamura K, Stecher G, Peterson D, et al. MEGA6: molecular evolutionary genetics analysis version 6.0. Mol Biol Evol. 2013;30:2725-9.

29. Benson DA, Cavanaugh M, Clark K, Karsch-Mizrachi I, Lipman DJ, Ostell J, Sayers EW. GenBank. Nucl Acids Res. 2016;45(D1):D37-42.

30. Behnke JM, Bajer A, Harris PD, Newington L, Pidgeon E, Rowlands G, et al. Temporal and between-site variation in helminth communities of bank voles (Myodes glareolus) from N.E. Poland. 1. Regional fauna and component community levels. Parasitology. 2008;135(8):985-97.

31. Behnke JM, Bajer A, Harris PD, Newington L, Pidgeon E, Rowlands G, et al. Temporal and between-site variation in helminth communities of bank voles (Myodes glareolus) from N.E. Poland. 2. The infracommunity level. Parasitology. 2008;135(8):999-1018.

32. Grzybek M, Bajer A, Bednarska M, Al-Sarraf M, Behnke-Borowczyk J, Harris PD, et al. Long-term spatiotemporal stability and dynamic changes in helminth infracommunities of bank voles (Myodes glareolus) in NE Poland. Parasitology. 2015;142(14):1722-43.

33. Hildebrandt A, Hunfeld KP, Baier M, Krumbholz A, Sachse S, Lorenzen T, et al. First confirmed autochthonous case of human Babesia microti infection in Europe. Eur J Clin Microbiol Infect Dis. 2007;26(8):595-601.

34. Welc-Faleciak R. Pasożyty krwi gryzoni Babesia microti i Bartonella spp. patogenne dla człowieka: badania środowiskowe i molekularne. Warsaw: Warsaw University; 2006

35. Welc-Faleciak R, Bajer A, Bednarska M, Paziewska A, Sinski E. Long term monitoring of Babesia microti infection in BALB/C mice using nested PCR. Ann Agric Environ Med. 2007;14(2):287-90.

36. Kozakiewicz M. The role of habitat isolation in formation of structure and dynamics of the bank vole population. Acta Theriol. 1985;30(10):193-209.

37. Karbowiak G, Stanko M, Rychlik L, Nowakowski W, Siuda K. The new data about zoonotic reservoir of Babesia microti in small mammals in Poland. Acta Parasitol. 1999;44(2):142-4

38. Karbowiak G, Rychlik L, Nowakowski W, Wita I. Natural infections of small mammals with blood parasites on the borderland of boreal and temperate forest zones. Acta Theriol. 2005;50(1):31-42.
39. Obiegala A, Pfeffer M, Pfister K, Karnath C, Silaghi C. Molecular examinations of Babesia microti in rodents and rodent-attached ticks from urban and sylvatic habitats in Germany. Ticks Tick Borne Dis. 2015;6(4):445-9.

40. Sebek Z. Blood parasites of small wild mammals in Czechoslovakia. Folia Parasitol. 1975;22(1):11-20.

41. Sebek Z, Rosicky B, Sixl W. The occurrence of babesiasis affecting small terrestrial mammals and the importance of this zoonosis in Europe. Folia Parasitol. 1977;24(3):221-8.

42. Sebek Z, Sixl W, Stunzner D, Valova M, Hubalek Z, Troger H. Blood parasites of small wild mammals in Steiermark and Burgenland. Folia Parasitol. 1980; 27(4):295-301.

43. Baker JR, Chitty D, Phipps E. Blood parasites of wild voles, Microtus agrestis, in England. Parasitology. 1963;53(1-2):297-301.

44. Bown KJ, Lambin X, Telford GR, Ogden NH, Telfer S, Woldehiwet Z, et al. Relative importance of Ixodes ricinus and Ixodes trianguliceps as vectors for Anaplasma phagocytophilum and Babesia microti in field vole (Microtus agrestis) populations. Appl Environ Microbiol. 2008;74(23):7118-25.

45. Healing TD. Infections with blood parasites in the small British rodents Apodemus sylvaticus, Clethrionomys glareolus and Microtus agrestis. Parasitology. 1981;83(Pt 1):179-89.

46. Bown KJ, Lambin X, Telford G, Heyder-Bruckner D, Ogden NH, Birtles RJ. The common shrew (Sorex araneus): a neglected host of tick-borne infections? Vector Borne Zoonotic Dis. 2011;11(7):947-53.

47. Cox FEG. Parasitic protozoa of British wild mammals. Mammal Rev. 1970; $1(1): 1-28$.

48. Krampitz HE, Bäumler W. Occurrence, host range and seasonal prevalence of Babesia microti (França, 1912) in rodents of southern Germany. Z Parasitenkd. 1978;58(1):15-33. doi:10.1007/bf00930788.

49. Wenk P, Renz A. Parasitism and evolution: opposing versus balancing strategies. Hist Biol. 2013;25(2):251-9.

50. Sinski E. Enzootic reservoir for new Ixodes ricinus-transmitted infections. Wiad Parazytol. 1999:45(2):135-42.

51. Schmidt KA, Ostfeld RS. Biodiversity and the dilution effect in disease ecology. Ecology. 2001;82(3):609-19.

52. Rar VA, Epikhina TI, Livanova NN, Panov W. Genetic diversity of Babesia in Ixodes persulcatus and small mammals from North Ural and West Siberia, Russia. Parasitology. 2011;138(2):175-82.

53. Rar VA, Epikhina TI, Livanova NN, Panov W, Pukhovskaia NM, Vysochina NP, et al. Detection of Babesia spp. DNA in small mammals and ixodic ticks on the territory of north Ural, west Siberia and far east of Russia. Mol Gen Mikrobiol Virusol. 2010;3:26-30.

\section{Submit your next manuscript to BioMed Central and we will help you at every step:}

- We accept pre-submission inquiries

- Our selector tool helps you to find the most relevant journal

- We provide round the clock customer support

- Convenient online submission

- Thorough peer review

- Inclusion in PubMed and all major indexing services

- Maximum visibility for your research

Submit your manuscript at www.biomedcentral.com/submit 